and shows how a desert region of Western Siberia was transformed in twenty-five years into an industrial centre of 400,000 inhabitants. The site is 400 miles from the nearest large town and endures a winter temperature of $-50^{\circ} \mathrm{C}$. About 50 per cent of the electric power of the plant is obtained from waste products. The town is supplied with waste heat and gas from the coking plant. Other indus. tries, for example, a cement factory and a foodprocessing works, are integrated with the combine.

The question of the best method of using power for metal production attracted some interest. One paper describes the methods of production of the light metals, aluminium, magnesium, titanium and beryllium, both by electrolytic and thermal processes; another, the production of ferro alloys (silicon, chromium, manganese); and a third the economics of producing pig-iron and steel electrically. As a rough rule, it is stated that economic equilibrium is attained between blast and electric furnaces for pigiron production when the price of $1 \mathrm{kgm}$. of coal is about five times greater than the price of $1 \mathrm{kWh}$. of electricity. For countries with a surplus of waterpower the electrolytic production of hydrogen is suggested. This can be used as a raw material in nitrogen factories for fertilizer and other chemicals. The electrolysis of water at 30 atmospheres is described as being very efficient and requiring few personnel.

Generally the suggestion is that countries with large resources of power, particularly hydro-power, should encourage the construction of a large integrated metallurgical industry.

The Conference reviewed many aspects of development and much detailed information is published. There is little that is completely new except for the desire of the backward countries, now gradually being realized, to equip themselves with power resources. There was a growing awareness that many problems can only be solved by international cooperation, and that the world is becoming a single economic unit. The day must come when national power systems become international systems and international systems become continental power grids.
F. D. Robinson

\title{
OBITUARIES
}

\section{Dr. G. A. Steven}

George Arexander Steven, whose death occurred on April 7 at his home in Yelverton, South Devon, was born at Freswick, Caithness, on April 13, 1901. $\mathrm{He}$ was an undergraduate at the University of Edinburgh during 1924-28, being Vans Dunlop Scholar in 1926. He was appointed student probationer at the Plymouth Laboratory of the Marine Biological Association of the United Kingdom in 1928, and joined the permanent staff of the Laboratory in 1929 .

Steven, who had practical experience of the sea and fishing in his youth, studied chiefly the biology of commercial fishes, especially the rays and skates and the mackerel. His comprehensive survey of the biology and fishery of the mackerel in the English Channel and its western approaches formed a noteworthy contribution to our knowledge of that species. $\mathrm{He}$ also undertook special investigations to assess the possible damage to local fisheries in Devon and Cornwall by seals, and shags and cormorants. In the study of seals he visited all the likely caves on the north coast of Cornwall and made a census of the population.

In 1939 he accepted the post of director of the Newfoundland Fisheries Research Laboratory at St. Johns, in succession to Dr. Harold Thompson. Almost immediately, however, the St. Johns Laboratory was destroyed by fire, and further activities were curtailed by the outbreak of war. After his war service he decided to remain on the staff of the Plymouth Laboratory.

Steven saw service with the Expeditionary Force in France in the First World War, and in the Second World War he served in the Royal Navy. During 1942-45 he was seconded from the Navy to act as fishery development officer of Sierra Leone under the Colonial Office. He was based at Freetown, and under the many difficulties created by the circumstances of war he helped to lay the foundations for post-war fisheries development in West Africa.

His practical knowledge of fishing vessels was put to good use in the assistance he gave in the design and equipment of the Association's research vessel
Sarsia. His interest in fishing gear led to the writing of a small book entitled "Nets: How to Make, Mend and Preserve Them", which proved very successful. During 1930-40 and 1946-48 he took part in the supervision of the university students' Easter courses at the Plymouth Laboratory. Steven was a D.Sc. of the University of Edinburgh and Fellow of the Royal Society of Edinburgh.

The sympathy of his many friends will go to his widow and two sons.

F. S. RUSSELI

\section{Mr. Frank Kingdon-Ward, O.B.E.}

WITH the passing of Frank Kingdon-Ward on April 8, at the age of seventy-two, the last of the great plant collectors and explorers in the ForrestFarrar tradition has left the scene. It is now no longer possible for westerners to travel alone for months in the vast areas of Tibet, north Burma and western China, where many of the best of the plants now cultivated in our gardens are to be found in their native habitats. Perhaps the artificial barriers which now block the way will one day be lifted but, in any event, conditions have changed. The aeroplane saves weeks of foot-slogging, and modern medicine provides the prophylaxis to keep the traveller fit. No doubt soon the helicopter will deposit the plant collector on the tops of mountains which it would otherwise have taken months to reach.

Those who are prepared to accept the penalties of one-man exploration-the physical hardship, the utter loneliness of months in a strange land among strange people, the nauseating dullness of a diet of tsampa washed down with rancid butter tea and all the inconvenience of travelling 'light', must possess exceptional courage, determination, loyalty to their sponsors and devotion to their purpose. These qualities, combined with modesty-for all the great explorers were modest men-are qualities which make men great and Kingdon-Ward possessed them in full measure. He was no mere explorer and plant collector. It is true that his contributions to our knowledge of the geography of Tibet, north Burma 
and western China were considerable and he made many notable introductions to beautify our gardens. In fact he had done enough in these two fields to have made a name for himself and, indeed, he received many honours from the Royal Geographical Society and the Royal Horticultural Society. He was, however, no mean botanist, plant geographer and plant ecologist, and he wrote much and well on these subjects.

All his expeditions, except the last four, were oneman efforts, and the amount of work he accomplished was outstanding. His specimens were beautifully collected and the notes on them copious. His photography was of a very high standard, and, of course, he was an expert seed-collector.

On his last four expeditions he was accompanied by his wife Jean (née Macklin), to whose devotion and care he himself freely admitted the success of these ventures was due. She has the sympathy of all who knew Frank Kingdon-Ward and of the many who know him only through his books and through the objects of beauty, his own introductions, which adorn our gardens.

N. L. Bor

\section{Mr. S. B. Smith}

Mr. S. B. SMrTH, who died recently at the age of sixty-six, was associated with some of the earliest engineering developments of Marconi's Wireless Telegraph Co. during forty-four years service until his retirement in 1956. He is probably best known for his investigations into the technique of radio direction-finding, which he started during the First World War and continued in the Company's Research Department which he joined in 1919. He studied the effects of wave polarization on closed-loop aerial systems, and took a leading part in the commercial design and development of the Adcock directionfinder, particularly for use at high radio-frequencies and at long ranges. This resulted in spectacular advances in direction- and position-finding; and the system of greatly improved accuracy found extensive application before and during the Second World War.

Mr. Smith also participated in the development of photo-telegraphy (facsimile transmission) ; and made a major contribution to the design of the early automatic high-speed commercial services from Chelmsford to European capitals, being largely responsible for the development of the first of such equipments installed by Marconi's in Geneva for the League of Nations.

During the Second World War he was engaged on highly specialized work for the Admiralty and, until he retired in 1956, was consulted by the Armed Services as a leading authority on wave propagation and high-frequency direction-finding. At the time of his retirement he was chief of the Patents Department of Marconi's.

Mr. Smith was for many years a valued member of the Direction-Finding Committee of the Radio Research Board of the Department of Scientific and Industrial Research. He also took an active part in the work of many international committees and conferences convened to discuss the organization of world radio communications. $\mathrm{He}$ will be remembered by his contemporaries for his sound judgment in the support of new ideas, and with affection by the many to whom, as young engineers, he extended encouragement and assistance.

\section{NEWS and VIEWS}

\section{National Institute for Research in Dairying : Prof. H. D. Kay, C.B.E., F.R.S.}

PROF. H. D. KAY, who is to retire in September from the directorship of the National Institute for Research in Dairying, was born in Heaton Chapel, attended the Manchester Grammar School and then the University of Manchester. After military service in the First World War, during which he was awarded the O.B.E. (Military Division), he worked with H. S. Raper in the University of Leeds and then as Beit Memorial Fellow with Harden at the Lister Institute and with Knoop in Freiburg, moving from there to Hopkins's laboratory in Cambridge, where he gained his Ph.D. From a post in the London Hospital, which he held for four years, obtaining in the meantime the degree of D.Sc. from the University of Manchester, he was called to Toronto to a chair of biochemistry. In 1932 he was invited to succeed the late Dr. Stenhouse Williams, first director of the National Institúte for Research in Dairying, a post he has held for twentysix years together with that of research professor in biochemistry in the University of Reading. Under his directorship the scope and size of the Institute have increased markedly, from some twenty research workers in four departments in 1932 to more than five times that number in nine departments and two independent sections at present. His interest in phosphorus compounds, begun in the London Hospital, culminated in the discovery of the phosphatase test for the efficiency of milk pasteurization, which has gained world-wide application. Elected to the Royal Society in 1945, Prof. Kay was made C.B.E. in 1946. To the exacting work of directing a large institute he has added service on many government scientific committees and advisory work for the Food and Agriculture Organization of the United Nations. Hard physical exercise has been his escape from sedentary duties and, a keen gardener, he has for many years been president of the Reading Horticultural Association. A good athlete in his younger days and an intrepid walker at all times, Prof. Kay retires at a youthful sixty-five to take up a special assignment with the Food and Agriculture Organization. He takes with him the wishes of numerous friends for a happy, energetic and industrious retirement.

\section{Royal Agricultural Society of England: Award of Research Medal}

The Research Medal of the Royal Agricultural Society of England has been awarded to Dr. W. A. Sexton and Mr. W. G. Templeman.

Dr. W. A. Sexton was co-discoverer, with Mr. W. G. Templeman, in 1940 of hormone and carbamate weed-killers. In $1935 \mathrm{Dr}$. Sexton joined a section of the Research Department of the Dyestuffs Department, Imperial Chemical Industries, at Brackley, working on the synthesis of products for the control 